\title{
Slawomira Kańdula*
}

\section{PROJEKT ZMIAN MECHANIZMU \\ WYRÓWNANIA FINANSOWEGO DLA GMIN \\ NA TLE POSTULATÓW TEORII FEDERALIZMU FISKALNEGO}

\begin{abstract}
Streszczenie
Artykuł odwołuje się do systemu dochodów uzupełniających gmin w Polsce, w szczególności do mechanizmu wyrównania finansowego adresowanego do tych jednostek. Jego celem jest charakterystyka i ocena ministerialnej koncepcji zmian w tym systemie, zaprezentowanej w czerwcu 2015 roku, na tle postulatów teorii federalizmu fiskalnego. W artykule stwierdzono, że proponowane rozwiązania wychodzą przede wszystkim naprzeciw postulatowi wyrównywania różnic w potrzebach wydatkowych gmin. Uwzględnia się w nich też specyfikę niektórych gmin (liczbę ludności w małych gminach, gęstość zaludnienia). Niektóre zmiany odwołują się nie tyle do postulatów teoretycznych, ile do dysfunkcji mechanizmu redystrybucji poziomej, które potwierdził Trybunał Konstytucyjny.
\end{abstract}

Słowa kluczowe: teoria federalizmu fiskalnego, dochody gmin, mechanizm wyrównawczy

\section{Wprowadzenie}

W połowie czerwca 2015 roku przedstawiono, sygnowany przez Ministerstwo Finansów, zarys zmian w systemie zasilania zewnętrznego jednostek samorządu terytorialnego (JST), w tym w mechanizmie wyrównawczym. Bezpośrednim

* Sławomira Kańduła, dr, Uniwersytet Ekonomiczny w Poznaniu, Wydział Ekonomii, e-mail: s.kandula@ue.poznan.pl. 
impulsem do podjęcia prac nad zmianą ustawy o dochodach tych jednostek z 2003 roku $^{1}$ były wyroki i postanowienie sygnalizacyjne Trybunału Konstytucyjnego ${ }^{2}$, który zalecił zmianę dyskusyjnych rozwiązań prawnych. Do najważniejszych dysfunkcji systemu zasilania zewnętrznego JST, w szczególności mechanizmu wyrównawczego, zaliczono: brak gwarancji zachowania istotnej części dochodów własnych; brak zabezpieczeń przed nadmiernym ubytkiem dochodów własnych w okresie dekoniunktury; możliwość spadku dochodów JST dokonujących wpłat wyrównawczych poniżej dochodów przeciętnych; przekazywanie środków pochodzących z wpłat także tym JST, które ich dokonują i nie są najuboższymi; nieuwzględnienie specyfiki dużych miast oraz struktury demograficznej i sezonowego przypływu ludności; ograniczenie kryteriów ustalania beneficjentów części równoważącej do wybranych dochodów i wydatków własnych ${ }^{3}$. Po wyrokach doraźnie zmodyfikowano zasady wnoszenia wpłat wyrównawczych województw w 2015 i 2016 roku, podjęto też prace nad docelowym kształtem systemu zasilania zewnętrznego JST.

Upubliczniony projekt zmian w ustawie o dochodach JST jest bardzo ogólny, nie towarzyszą mu też symulacje skutków finansowych dla JST i państwa, niemniej jednak zasadne jest podjęcie dyskusji nad proponowanymi rozwiązaniami. Celem artykułu jest ocena przedstawionego w czerwcu 2015 roku zarysu projektu zmian w konstrukcji mechanizmu wyrównawczego dla gmin z punktu widzenia spełnienia postulatów teorii federalizmu fiskalnego odnoszących się do pożądanego kształtu tego mechanizmu.

\section{Dochody wyrównawcze gmin w świetle teorii federalizmu fiskalnego - wybrane zagadnienia}

Państwo udziela gminom subwencji i dotacji z wielu powodów, ale rozważania w tym punkcie prowadzone są tylko w kontekście transferów przekazywanych w związku ze zjawiskiem poziomej nierównowagi fiskalnej, która przejawia poz. 513 .

${ }^{1}$ Ustawa z 13.11.2003 r. o dochodach jednostek samorządu terytorialnego, t.j. DzU z 2015 r.,

2 Wyrok Trybunału Konstytucyjnego z 31.01 .2013 r., sygn. akt K 14/11 uzupełniony o postanowienie Trybunału Konstytucyjnego z 26.02.2013 r., sygn. akt S 1/13 oraz wyrok Trybunału Konstytucyjnego z 4.03.2014 r., sygn. akt K 13/11, http://trybunal.gov.pl/rozprawy/wyroki (15.04.2014).

${ }^{3}$ Dysfunkcje mechanizmu redystrybucji poziomej i wyroki Trybunału omawia szerzej H. Izdebski w: Funkcjonowanie instytucji wpłat na subwencję ogólna (,janosikowe”) z punktu widzenia finansów m.st. Warszawy i województwa mazowieckiego, „Samorząd Terytorialny” 2013, nr 11, s. 5-16. 
się w zróżnicowaniu dochodów i wydatków własnych gmin na mieszkańca i uzasadnia ich wyrównywanie w procesie redystrybucji pionowej i poziomej. System instrumentów finansowych ustanawianych przez państwo (organy centralne) $\mathrm{w}$ danym czasie w celu wyrównania istniejących między gminami różnic w wysokości ich dochodów własnych (zdolności dochodowej) lub ich wydatków na zadania własne (potrzeb wydatkowych) na mieszkańca oraz prawne, organizacyjne i planistyczne ramy ich stosowania obejmuję mianem mechanizmu wyrównawczego (wyrównania finansowego). Oba rodzaje różnic łączę w pojęciu (międzygminnych) różnic (nierówności) fiskalnych.

Tak rozumiany mechanizm wyrównawczy można scharakteryzować, biorąc pod uwagę jego podstawowe komponenty (wymiary) tj. jego cel (przedmiot), podejście do wyrównania i jego zakres, instrumenty osiągania założonego celu i źródła ich finansowania oraz organizację procesu wyrównywania międzygminnych różnic fiskalnych.

Celem polityki wyrównawczej państwa prowadzonej w samorządowym podsektorze finansów publicznych może być wyrównywanie różnic w zdolności dochodowej gmin lub w ich potrzebach wydatkowych w przeliczeniu na jednego mieszkańca. Przez zdolność tę należy rozumieć możliwości osiągania dochodów własnych, w szczególności z podatków i opłat lokalnych. Szacuje się ją zwykle przy założeniu, że wszystkie gminy pobierają daniny lokalne według takich samych lub średnich dla państwa stawek podatkowych i pomija się ubytek dochodów spowodowany stosowaniem preferencji podatkowych. Z kolei określenie ,potrzeby wydatkowe gmin” używane jest w znaczeniu minimalnej kwoty środków niezbędnych do zaspokojenia standardowych potrzeb z zakresu obowiązkowych zadań własnych o charakterze bieżącym ${ }^{4}$. Wyrównywaniu różnic w tych potrzebach powinno towarzyszyć określenie standardowych wydatków lub standardowego koszyka lokalnych usług publicznych.

Konstrukcji systemu zasilania zewnętrznego przyświeca określona filozofia, mówi się więc o czterech modelach wyrównywania różnic fiskalnych: jednolitym, asymetrycznym, aktywizującym [konkursowym] i specyficznym ${ }^{5}$. W pierwszym transfery finansowane są zwykle z jednego źródła, a podział środków odbywa się na podstawie jednej formuły zawierającej jednolite kryteria

${ }^{4}$ A. Reschovsky, Compensating Local Governments for Differences in Expenditure Needs in a Horizontal Fiscal Equalization Program, w: Intergovernmental Fiscal Transfers Principles and Practice, The World Bank, Washington 2007, s. 400.

5 P.B. Spahn, Equity and Efficiency Aspects of Intragency Transfers in a Multigovernment Framework, w: Intergovernmental Fiscal Transfers Principles and Practice, The World Bank, Washington 2007, s. 78-80. 
dla wszystkich gmin. W drugim odmienne rozwiązania prawne są stosowane w odniesieniu do tych gmin, które charakteryzują się określoną specyfiką, np. wykonują więcej zadań, mieszka w nich więcej osób, są słabiej zaludnione, położone peryferyjnie. W modelu aktywizującym gminy rywalizują o środki budżetu państwa, przygotowując wnioski o dofinansowanie zadań i przystępując do konkursów. Model specyficzny ma zastosowanie do wyrównywania różnic międzyregionalnych; transfery finansowane są z budżetu państwa, ich przeznaczenie jest ściśle powiązane z celami polityki regionalnej państwa, więc są one dostępne jedynie dla regionów zapóźnionych gospodarczo.

W konstrukcji mechanizmu wyrównawczego trzeba określić zakres (skalę) wyrównania różnic fiskalnych. Nie można w tym względzie podać optymalnego wzorca, ponieważ ludzie mają odmienne poczucie sprawiedliwości, a jej satysfakcjonujący poziom może być sprzeczny z dążeniem do maksymalizacji dobrobytu w całym państwie ${ }^{6}$. Wyróżnić można trzy modele zakresu wyrównania: pełne, częściowe, minimalne ${ }^{7}$ oraz różne wielkości, w odniesieniu do których zakres ten może być ustalany. Punktem odniesienia może być np. przeciętny poziom dochodów i wydatków wszystkich gmin per capita, gmin danego typu administracyjnego, lub określonej ich grupy wyodrębnionej ze względu na liczbę mieszkańców bądź wielkość powierzchni.

Elementem rozpatrywanego mechanizmu jest też konstrukcja transferu wyrównawczego, na którą składają się: jego rodzaj, kryteria wyboru gmin uprawnionych do jego otrzymania, sposób kalkulacji środków i ich wyodrębniania z puli środków wyrównawczych oraz kryteria ich podziału pomiędzy uprawnione podmioty. Z konstrukcją tą wiąże się źródło finansowania transferu, które determinuje kanał przepływu środków wyrównawczych (redystrybucja pionowa, pozioma, mieszana).

Ostatnim elementem rozpatrywanego mechanizmu jest jego model organizacyjny, przez który należy rozumieć instytucjonalny układ podmiotów zajmujących się przygotowywaniem propozycji dotyczących - szeroko rozumianego - kształtu mechanizmu wyrównawczego (i jego zmian), obliczaniem transferów, ich przekazywaniem i (ewentualnie) rozliczaniem. Wyróżnić można trzy takie modele: angielski, kontynentalny, pośredni. Najogólniej można przyjąć, że w pierwszym z nich najważniejszą rolę odgrywa niezależna komisja finansowa,

${ }^{6}$ E. Ahmad, G. Brosio, Introduction: Fiscal Federalism - a Review of Developments in the Literature and Policy, w: Handbook of Fiscal Federalism, Edward Elgar, Cheltenham, Northampton 2008, s. 20.

7 B. Dafflon, Fiscal Decentralization, s. 95-96, www.ciesin.columbia.edu/decentralization/English/Issues/Fiscal_d.pdf (23.04.2013). 
w drugim minister finansów lub spraw wewnętrznych, a w trzecim uprawnienia obu podmiotów są równorzędne.

Tabela 1

Zasady konstruowania systemu zasilania zewnętrznego gmin, w tym mechanizmu wyrównawczego

\begin{tabular}{|c|c|}
\hline Nazwa zasady ${ }^{a}$ & Treść zasady \\
\hline $\begin{array}{l}\text { Zasada konsekwencji } \\
\text { celu }\end{array}$ & Transfery powinny mieć jeden jasno określony cel \\
\hline Zasada przejrzystości & $\begin{array}{l}\text { Transfery powinny być dzielone na podstawie prostych, obiektywnych } \\
\text { i jasnych kryteriów }\end{array}$ \\
\hline $\begin{array}{l}\text { Zasada stabilności } \\
\text { (przewidywalności) }\end{array}$ & $\begin{array}{l}\text { Rodzaje transferów i zasady ich przyznawania powinny być względnie } \\
\text { stałe }\end{array}$ \\
\hline $\begin{array}{l}\text { Zasada sprawiedli- } \\
\text { wości }\end{array}$ & $\begin{array}{l}\text { Wysokość przekazywanych środków publicznych powinna być propor- } \\
\text { cjonalna do potrzeb wydatkowych JST i odwrotnie proporcjonalna do ich } \\
\text { zdolności dochodowej (możliwości gromadzenia dochodów własnych) }\end{array}$ \\
\hline $\begin{array}{l}\text { Zasada samodzielno- } \\
\text { ści (i odpowiedzial- } \\
\text { ności) }\end{array}$ & $\begin{array}{l}\text { Jednostka samorządu terytorialnego powinna mieć swobodę w wydat- } \\
\text { kowaniu środków pochodzących z transferów, a jednocześnie ponosić } \\
\text { odpowiedzialność za rezultaty swej działalności }\end{array}$ \\
\hline $\begin{array}{l}\text { Zasada uwzględniania } \\
\text { specyfiki JST }\end{array}$ & $\begin{array}{l}\text { Konstrukcja transferów powinna uwzględniać specyfikę JST różnych } \\
\text { szczebli samorządu terytorialnego, różnych typów administracyjnych } \\
\text { (np. miejska, wiejska), pełniących odmienne funkcje, różnych pod wzglę- } \\
\text { dem liczby mieszkańców i innych kryteriów }\end{array}$ \\
\hline $\begin{array}{l}\text { Zasada przezornej } \\
\text { alokacji }\end{array}$ & $\begin{array}{l}\text { Konstrukcja transferów powinna uniemożliwiać powstawanie miękkich } \\
\text { ograniczeń budżetowych oraz zjawiska pogoni za rentą (podejmowania } \\
\text { strategicznych działań w celu otrzymania wyższego transferu) }\end{array}$ \\
\hline $\begin{array}{l}\text { Zasada systemu } \\
\text { bodźców }\end{array}$ & $\begin{array}{l}\text { System transferów powinien stwarzać bodźce do racjonalnego gospo- } \\
\text { darowania środkami publicznymi, stymulowania wysiłku dochodowego } \\
\text { i rozwoju lokalnego }\end{array}$ \\
\hline Zasada ewaluacji $^{\mathrm{b}}$ & $\begin{array}{l}\text { Należy przewidzieć możliwość okresowego kontrolowania efektów prze- } \\
\text { kazywanych transferów i ich wpływu na wysokość dochodów własnych }\end{array}$ \\
\hline \multicolumn{2}{|c|}{$\begin{array}{l}\text { Nazwy zasady pochodzą od autorki. } \\
\text { ' Zwana także zasadą zachodzącego słońca (sunset clauses). }\end{array}$} \\
\hline
\end{tabular}

Literatura nie podaje gotowych wzorców wszystkich komponentów mechanizmu wyrównawczego. Można w niej znaleźć jedynie rekomendacje odnoszące się do niektórych z nich, mianowicie ${ }^{8}$.

8 Zob. np. omawianą w literaturze rekomendację Komitetu Rady Europy nr 1/2005 z 19.01.2005 r., https://wcd.coe.int/ViewDoc.jsp?id=812131\&Site=COE (31.03.2014). 
1. Pożądane jest wyrównywanie różnic w zdolności dochodowej i potrzebach wydatkowych gmin na mieszkańca.

2. Pożądane jest uwzględnianie specyfiki określonych grup gmin, np. wiejskich, dużych miast, położonych peryferyjnie.

3. Wskazane jest, aby wyrównanie nie osłabiało aktywności gmin ukierunkowanej na stymulowanie rozwoju gospodarczego, pomnażanie źródeł dochodów własnych i wzrost wysiłku dochodowego.

4. Transfer wyrównawczy powinien mieć charakter ogólny, a zasady wyboru gmin uprawnionych do jego otrzymania, sposób kalkulacji środków i ich wyodrębniania z puli środków wyrównawczych oraz kryteria podziału jasne, względnie stałe $\mathrm{i}$ zapisane w przepisach prawnych rangi ustawowej.

Kształt projektowanego mechanizmu wyrównawczego jest zawsze zdeterminowany następującymi okolicznościami: typem państwa i przyjętym modelem samorządu terytorialnego, systemem jego dochodów własnych, celami przypisanymi subwencjom i dotacjom, możliwościami budżetu państwa, możliwościami dokonywania wpłat przez JST biernie uczestniczące w redystrybucji poziomej, przyjętą doktryną społeczną wyznaczającą poczucie sprawiedliwości oraz doświadczeniami historycznymi, w tym wynikającymi z krytyki dotychczasowego mechanizmu. Pomimo istnienia specyficznych dla danego państwa uwarunkowań w literaturze postuluje się, aby system zasilania zewnętrznego JST zbudowany był z uwzględnieniem określonych zasad (tab. 1).

\section{Charakterystyka projektu zmian $w$ systemie zasilania zewnętrznego gmin $^{9}$}

Propozycje ujęte w projekcie zmian w systemie zasilania zewnętrznego gmin można podzielić na: 1) odnoszące się do ich systemowych dochodów własnych, 2) modyfikujące filozofię części wyrównawczej subwencji ogólnej (zwanej dalej w skrócie subwencją wyrównawczą) oraz 3) dotyczące zmian w przepływie środków wyrównawczych, w tym w mechanizmie redystrybucji poziomej.

Pierwsza zmiana, której intencją jest zdywersyfikowanie źródeł dochodów własnych, polega na przyznaniu gminom udziału w podatku od towarów i usług

9 Punkt napisano na podstawie prezentacji multimedialnej pt. System subwencji $i$ wplat do budżetu państwa z dnia 15.06.2015, którą zamieszczono na stronie internetowej Ministerstwa Finansów. W momencie jego powstawania autorka nie dysponowała pełną informacją na temat przygotowywanych zmian. 
przy jednoczesnym zmniejszeniu wskaźnika procentowego udziału w podatku dochodowym od osób prawnych. Projektodawcy spodziewają się, że spowoduje to zmniejszenie różnic fiskalnych między gminami (w ich dochodach podatkowych) oraz wpłynie korzystnie na stabilizację dochodów (zmniejszy ich wrażliwość na wahania cyklu koniunkturalnego). Nie określono jednak ani wskaźnika procentowego obu udziałów, ani zasad ich naliczania.

Ze względu na to, że w Polsce udziały w podatkach państwowych są zaliczane do dochodów własnych JST, szczegółowa ocena proponowanego rozwiązania zostanie pominięta, niemniej jednak podkreślenia wymaga przynajmniej jeden problem. Udział w podatku od towarów i usług nie może być udziałem $\mathrm{w}$ takim samym rozumieniu jak udział w podatku dochodowym od osób prawnych (czy fizycznych), tzn. kwota podatku trafiająca do budżetu danej gminy musi być oderwana od miejsca zapłaty podatku. Odmienne rozwiązanie doprowadziłoby do narastania różnic dochodowych między gminami i konieczne byłoby ich uwzględnianie w systemie transferów wyrównawczych finansowanych z budżetu państwa lub z budżetów innych gmin. Oba rozwiązania niepotrzebnie komplikowałyby przepływy finansowe w sektorze finansów publicznych. Udział w wymienionym podatku pośrednim musiałby być obliczany na poziomie budżetu państwa, np. w jednakowej kwocie na mieszkańca rzeczywistego lub przeliczeniowego lub z uwzględnieniem określonych kryteriów ${ }^{10}$.

Modyfikacja subwencji wyrównawczej polega na zmianie: przedmiotu wyrównania, kryteriów wyznaczania jej beneficjentów oraz organizacji przepływu środków wyrównawczych. Przewiduje się, że nowa subwencja obliczana będzie z uwzględnieniem zróżnicowania potrzeb wydatkowych gmin, co jest zgodne z zaleceniami płynącymi z Europejskiej Karty Samorządu Lokalnego, z teorii federalizmu fiskalnego, z postulatami zgłaszanymi przez samorządowców oraz jest zbieżne z praktyką niektórych państw, w szczególności skandynawskich, Kanady, Niemiec oraz części państw Europy Środkowo-Wschodniej (np. państw nadbałtyckich) ${ }^{11}$. W omawianym projekcie nie zdefiniowano pojęcia potrzeb wydatkowych gmin, przyjęto jednak, że będą one obliczane na podstawie wysokości wybranych wydatków bieżących gmin „netto” (WBN). Na tym tle pod pojęciem wydatków bieżacych netto należy rozumieć wydatki bieżące ogółem

${ }_{10} \mathrm{~W}$. Gonet, Partycypacja samorzadu terytorialnego w podatkach pośrednich jako źródto dochodów, „Finanse Komunalne” 2012, nr 9, s. 18-20.

${ }_{11}$ P. Swianiewicz, Finanse samorzadowe. Koncepcje, realizacja, polityki lokalne, Wyd. Municipium, Warszawa 2011, s. 98-114; S. Kańduła, Wyrównywanie poziomej nierównowagi finansowej w budżetach gmin w państwach Europy Środkowo-Wschodniej, „Samorząd Terytorialny” 2015, nr 6, s. 38-56. 
z pominięciem wydatków bieżących na: oświatę (te zadania, które są uwzględnianie w części oświatowej subwencji ogólnej); zadania (projekty) finansowane ze środków UE; obsługę długu i wpłaty wyrównawcze; zadania dofinansowywane dotacjami z budżetu państwa. Nie określono jednak, czy mają to być tylko wydatki związane z zadaniami własnymi, czy również z zadaniami zleconymi. Za zasadniejsze należy uznać wyrównywanie różnic w potrzebach wydatkowych gmin tylko w zakresie ich zadań własnych.

Wydatki, które mają być uwzględniane w konstrukcji subwencji wyrównawczej, wyłoniono w czterech etapach. Na początku obliczono strukturę WBN według działów klasyfikacji budżetowej. Następnie wytypowano obiektywne czynniki zapotrzebowania (zmienne) wpływające na zróżnicowanie wysokości tych wydatków w tych trzech działach, w których są one najwyższe. Potem zbadano korelację między tymi czynnikami a wydatkami bieżącymi gmin w trzech ostatnich latach, na koniec zadaniom przypisano wagi świadczące o znaczeniu, jakie przywiązuje do nich rząd.

Najwyższe wydatki bieżące ,netto” ponoszone są przez gminy na zadania w działach: administracja publiczna $(31,1 \%)$, gospodarka komunalna i ochrona środowiska (15,7\%), pomoc społeczna (12,5\%), transport i łączność $(8,9 \%)$, kultura i ochrona dziedzictwa narodowego $(8,8 \%)$. Mankamentem omawianej propozycji jest to, że strukturę wydatków obliczono łącznie dla wszystkich gmin, a więc zarówno dla typowych gmin, jak i dla mających swoją specyfikę miast na prawach powiatu. Miasta te są z reguły gminami bogatszymi, więc mogą swobodniej kształtować politykę wynagradzania swoich pracowników, co mogło wpłynąć na wysokość WBN w poszczególnych działach, w szczególności w dziale administracja publiczna.

W następnym kroku dokonano doboru zmiennych świadczących o potrzebach wydatkowych gmin, ale tylko w odniesieniu do wydatków z zakresu administracji publicznej, gospodarki komunalnej oraz transportu. Przyjęto, że zmiennymi wpływającymi na zapotrzebowanie finansowe gmin na zadania z zakresu administracji jest liczba ludności, a na dwa pozostałe - gęstość zaludnienia. Doboru dokonano kierując się następującymi przesłankami: mierzalnością za pomocą danych statystycznych, niepodatnością na manipulacje oraz neutralnością z punktu widzenia bodźców do racjonalnego gospodarowania środkami publicznymi, w tym do prowadzenia skutecznej polityki rozwoju lokalnego.

W projekcie zamieszczono wybiórcze informacje na temat korelacji między czynnikami zapotrzebowania a wydatkami gmin na wybrane zadania w ciągu 3 lat. Wykazano, że istnieje korelacja dodatnia między zagęszczeniem ludności 
na $1 \mathrm{~km}^{2}$ a WBN gmin na transport. Nie podano jednak wartości wskaźnika korelacji i nie określono, dla jakich lat przeprowadzono obliczenia, oraz nie podano wyliczeń zależności dla innych zmiennych.

Ważnym etapem obliczania potrzeb wydatkowych gmin jest przypisanie poszczególnym kryteriom (czynnikom zapotrzebowania) wag. Problem doboru wag pojawia się wtedy, gdy na dane zjawisko oddziałuje wiele zmiennych i gdy celowe jest zróżnicowanie ich znaczenia. Zgodnie z ustaleniami statystyki wagi dobiera się bądź metodą uznaniową (ekspercką), bądź przy pomocy metod ilościowych ${ }^{12}$. Prawdopodobnie przypisanie wag nastąpiło z wykorzystaniem metod ilościowych. W materiale Ministerstwa Finansów zawarto informację, że w celu ich wyznaczenia gminy podzielono na grupy według tajemniczych „kryteriów skorelowanych z potrzebami wydatkowymi”, następnie wyliczono średnie WBN w grupach gmin oraz porównano je ze średnimi wydatkami wszystkich gmin. Procedura ta przywodzi na myśl metodę szacowania potrzeb wydatkowych gmin znaną jako representative expenditure system ${ }^{13}$. Czynniki zapotrzebowania i przypisane im wagi przedstawiono w tabeli 2.

Tabela 2

Czynniki zapotrzebowania finansowego gmin i przypisane im wagi

\begin{tabular}{|c|c|c|}
\hline Kryterium/czynnik zapotrzebowania & Waga & Grupa wydatków i uzasadnienie \\
\hline Gmina do 5 tys. mieszkańców & $+0,05$ & \multirow{2}{*}{$\begin{array}{l}\text { Wysokie koszty administracyjne } \\
\text { - efekty skali }\end{array}$} \\
\hline Gmina od 5 do 10 tys. mieszkańców & $+0,03$ & \\
\hline Gęstość zaludnienia do 20 osób na 1 km² & $+0,15$ & \multirow{4}{*}{$\begin{array}{l}\text { Gospodarka komunalna; rosnące koszty } \\
\text { utrzymania dróg lokalnych i sieci infra- } \\
\text { struktury komunalnej }\end{array}$} \\
\hline Gęstość zaludnienia $20-40$ osób na 1 km² & $+0,12$ & \\
\hline Gęstość zaludnienia 40-60 osób na 1 km² & $+0,10$ & \\
\hline Gęstość zaludnienia $60-80$ osób na 1 km² & $+0,06$ & \\
\hline $\begin{array}{l}\text { Gęstość zaludnienia od } 2500 \text { do } 3000 \\
\text { osób na } 1 \mathrm{~km}^{2}\end{array}$ & $+0,02$ & \multirow{2}{*}{$\begin{array}{l}\text { Transport publiczny; wzrost liczby użyt- } \\
\text { kowników wraz ze wzrostem zagęszczenia } \\
\text { ludności }\end{array}$} \\
\hline $\begin{array}{l}\text { Gęstość zaludnienia powyżej } 3000 \text { osób } \\
\text { na } 1 \mathrm{~km}^{2}\end{array}$ & $+0,03$ & \\
\hline
\end{tabular}

Źródło: System subwencji i wpłat do budżetu państwa, www.mf.gov.pl (20.06.2015).

12 T. Grabiński, Metody taksonometrii, Wydawnictwo Akademii Ekonomicznej w Krakowie, Kraków 1992, s. 34.

${ }_{13}$ A. Shah, Fiscal need equalization: Is it worth doing? Lessons from international practices, w: Measuring Local Government Expenditure Needs, The Korea Institute of Public Finance and the Danish Ministry of Social Welfare, Copenhagen 2008, s. 41. 
Nowa subwencja wyrównawcza ma być naliczana w określonej wysokości w relacji do przeliczeniowej liczby mieszkańców obliczanej następująco:

$$
\begin{gathered}
\text { Mieszkaniec przeliczeniowy }= \\
=\text { mieszkaniec faktyczny } \times(1+\text { suma wag potrzeb wydatkowych }) .
\end{gathered}
$$

W dalszym ciągu podstawowym kryterium jej przyznawania ma być niski poziom dochodów podatkowych, z tym że nie przedstawiono szczegółowych propozycji w tym zakresie. Zasygnalizowano jedynie, że podział ma następować z uwzględnieniem potrzeb wydatkowych gmin. Z opublikowanych materiałów nie wynika jednak, czy potrzeby te są już uwzględnione w koncepcji mieszkańca przeliczeniowego, czy też stosowane będą dodatkowe kryteria.

Zmieniony ma być też mechanizm redystrybucji poziomej. Po pierwsze, modyfikacjom w sposobie obliczania części wyrównawczej subwencji ogólnej ma towarzyszyć zmiana przepływu środków wyrównawczych, których wysokość będzie sumą środków wyrównawczych przewidzianych w budżecie państwa oraz środków pochodzących z wpłat gmin uznanych za bogate. Zlikwidowana więc zostanie część równoważąca subwencji ogólnej. Po drugie, wpłaty mają być obliczane na podstawie wskaźnika dochodów podatkowych na mieszkańca przeliczeniowego, a mają je wnosić gminy, w których wskaźnik ten będzie „znacznie wyższy niż średnia krajowa”. Nie określono jednak ani w jaki sposób obliczane będą dochody podatkowe, ani jaki będzie próg, po przekroczeniu którego dokonywane będą wpłaty (wiadomo, że ma być wyższy niż obecnie). Należy jednak zaznaczyć, że w przedstawionych założeniach znalazł się też zapis, że wysokość odprowadzanych wpłat będzie obniżona dla JST wszystkich szczebli, np. do poziomu 35\% dochodów podatkowych. Konstruując nową formułę wpłaty przyjęto założenie, że dochody podatkowe gmin po dokonaniu wpłaty nie mogą być niższe od średniego ich poziomu. Wpłaty obliczane będą wprawdzie na podstawie danych sprzed 2 lat $(n-2)$ w stosunku do roku ich dokonywania (n), z tym że w omawianych założeniach przewidziano obniżenie wpłat o $10 \%$ w sytuacji gdy suma dochodów JST za drugie półrocze roku $n-1$ oraz pierwsze półrocze roku n będzie niższa od $90 \%$ sumy dochodów za drugie półrocze roku $n-2$ oraz pierwsze półrocze roku $n-1$. W konsekwencji początkowo dzielone będzie tylko 90\% środków pochodzących z wpłat, a do 30 września roku budżetowego (roku n) Minister Finansów będzie informować o zwiększeniu subwencji wyrównawczej. Utworzona w ten sposób nowa część wyrównawcza dzielona będzie między gminy o najniższych dochodach. Kryteria podziału zostaną tak określone, że 
beneficjentami środków wyrównawczych nie będą gminy wpłacające nadwyżki swoich dochodów (dokonujące wpłat).

\section{Ocena ministerialnego projektu zmian wechanizmie wyrównawczym dla gmin}

Oceniając wstępny projekt zmian w mechanizmie wyrównawczym dla gmin na tle ustaleń literatury przedmiotu, należy stwierdzić, że wychodzi on naprzeciw postulatom wyrównywania różnic w zdolności dochodowej gmin (jak dotychczas) oraz $\mathrm{w}$ ich potrzebach wydatkowych na mieszkańca. Zaprezentowany materiał jest jednak na tyle ogólny i wybiórczy, że nie wynika z niego, czy w nowym systemie wymienione różnice wyrównywane będą przy pomocy oddzielnych transferów, czy też zostanie opracowana jedna formuła odnosząca się do wyrównania różnic między potrzebami wydatkowymi a możliwościami ich sfinansowania. Pierwsze podejście jest stosowane w państwach skandynawskich oraz państwach Europy Zachodniej, a drugie jest charakterystyczne dla państw Europy Środkowo-Wschodniej. Niezależnie od tego, które podejście zostanie zastosowane, zdolność dochodowa gminy obliczana będzie (prawdopodobnie) poprzez podzielenie jej potencjalnych dochodów podatkowych (jak obecnie) przez liczbę mieszkańców przeliczeniowych.

W tym miejscu trzeba się odnieść do koncepcji potrzeb wydatkowych gmin. Wspomniano już, że pojęcie to nie zostało zdefiniowane, wymieniono jedynie rodzaje wydatków bieżących, które pomija się przy szacowaniu tych potrzeb. Za uzasadnione uważam odnoszenie tych potrzeb tylko do wydatków na zadania własne o charakterze bieżącym. Jestem przekonana o zasadności pomijania wydatków na obsługę długu i wpłaty wyrównawcze oraz finansowanych ze środków UE i budżetu państwa. W ten sposób próbuje się „oczyścić” potrzeby wydatkowe z preferencji lokalnych i pomija się różną skuteczność gmin w ubieganiu się o dofinansowanie ze źródeł zewnętrznych oraz efektywność w wydatkowaniu tych środków. Idea pomijania wydatków na niektóre zadania oświatowe jest czytelna, ale $\mathrm{z}$ doświadczeń innych państw ${ }^{14}$ wynika, że wydatki na oświatę są składnikiem wskaźnika obrazującego potrzeby wydatkowe gmin. Jednak ich uwzględnianie byłoby równoznaczne z likwidacją obecnej części oświatowej subwencji ogólnej. Ujęcie we wskaźniku WBN wydatków finansowanych dotacjami ze źródeł

${ }_{14}$ Tak jest np. w Szwajcarii (S. Kańduła, Metodyka pomiaru potrzeb wydatkowych gmin, „Finanse Komunalne” 2015, w druku). 
zagranicznych oraz z budżetu państwa powodowałoby dwukrotne finansowanie tych samych wydatków z funduszy publicznych.

Niejasne jest to, dlaczego potrzeby wydatkowe gmin mają być obliczane tylko w odniesieniu do zadań z zakresu administracji publicznej, gospodarki komunalnej i transportu. Uwzględnianie wydatków na administrację jest koncepcją odmienną od przyjętej w innych państwach, choć są tutaj różne praktyki. Zróżnicowanie płac w administracji lokalnej uwzględnia się w Szwecji i Australii. Stałą dla wszystkich gmin wielkość potrzeb związaną z tymi wydatkami uwzględniano kiedyś w Danii, ale zrezygnowano z tego, ponieważ nie zachęcało to do łączenia się gmin. Dyskusyjne jest nie tylko wyrównywanie potrzeb odnoszących się do działu administracja publiczna, ale także pomijanie wielu innych ważnych zadań wykonywanych przez gminy, w szczególności z zakresu pomocy społecznej, które są uwzględniane w innych państwach, np. w Danii i Norwegii.

Dobrym rozwiązaniem jest obliczanie potrzeb wydatkowych na podstawie informacji o kształtowaniu się WBN gmin w okresie trzech lat poprzedzających obliczenie transferu. W ten sposób zapewnia się większą stabilizację wysokości przekazywanych kwot w poszczególnych latach oraz minimalizuje się wpływ nadzwyczajnych sytuacji powodujących znaczny wzrost lub spadek WBN.

W projektowanym systemie próbuje się respektować także postulat uwzględniania specyfiki gmin, z tym że jest ona określana pośrednio poprzez przypisanie wag do czynników zapotrzebowania obrazujących potrzeby wydatkowe wspólnoty. Próbuje się w ten sposób uwzględnić specyfikę gmin małych do 5 i do 10 tys. mieszkańców, gmin o niskiej gęstości zaludnienia (które zostały podzielone na cztery klasy; w pierwszej znalazły się gminy o gęstości zaludnienia do 20 osób na $1 \mathrm{~km}^{2}$, a w ostatniej te, w których na $1 \mathrm{~km}^{2}$ mieszka od 60 do 80 osób) oraz specyfikę gmin dużych (o czym świadczy przyjęcie dwóch wag - dla gmin o gęstości od 2500 do 3000 oraz powyżej 3000 osób na 1 km²). Należy w tym miejscu przypomnieć, że średnia gęstość zaludnienia w państwie wynosi 123 osoby na $1 \mathrm{~km}^{215}$. W projektowanym systemie nie uwzględnia się jednak (przynajmniej nie zapisano tego w upublicznionym materiale) specyfiki wynikającej z funkcji pełnionej przez gminę, jej typu administracyjnego, statusu prawnego (typowa gmina, miasto na prawach powiatu).

Na pełną ocenę przedmiotowego projektu z punktu widzenia zasad konstruowania systemu zasilania zewnętrznego gmin jest jeszcze za wcześnie, ponieważ w opublikowanym materiale nie zamieszczono informacji o wielu ważnych

15 Rocznik Statystyczny Rzeczypospolitej Polskiej 2014, GUS, Warszawa 2014, s. 82 i 205. 
elementach systemu dochodów uzupełniających dla gmin. Można jednak pokusić się o kilka spostrzeżeń.

W ustawie o dochodach JST z 2003 roku nie określano celu transferów, nie zapisano ich też $\mathrm{W}$ omawianym projekcie. W dotychczasowej praktyce przestrzegana była zasada stabilności systemu zasilania zewnętrznego gmin, prawdopodobnie będzie tak też dalej. Wydaje się, że projektowany mechanizm będzie respektował zasadę samodzielności gmin, bo wysokość transferu przekazywanego w związku z wyrównywaniem potrzeb wydatkowych będzie rosła wraz z liczbą mieszkańców przeliczeniowych.

Wszystko wskazuje na to, że w dalszym ciągu zachowana będzie ogólność transferu, o czym świadczy jego nazwa - część wyrównawcza subwencji ogólnej. W ten sposób przestrzegana będzie zasada samodzielności gmin. Prawdopodobnie utrzymana też będzie zasada ustawowego unormowania konstrukcji transferów wyrównawczych. Nie wiadomo jednak, na ile wyrównywanie różnic w potrzebach wydatkowych skomplikuje kryteria podziału środków wyrównawczych pomiędzy gminy, a więc czy respektowana będzie zasada przejrzystości. Przynajmniej częściowo spełniony zostanie postulat uwzględniania specyfiki gmin, o czym świadczy zróżnicowanie wag czynników zapotrzebowania dla małych gmin oraz gmin nisko i gęsto zaludnionych. Prawdopodobnie pominięte zostaną inne okoliczności wpływające na specyfikę potrzeb wydatkowych niektórych gmin (typ administracyjny, pełnione funkcje).

Czynniki zapotrzebowania dobrano tak, aby niemożliwe było manipulowanie ich wielkością w celu otrzymania wyższego transferu, co jest zgodne z zasadą przezornej alokacji. Trudno stwierdzić, czy w konstrukcji transferów w nowym systemie uwzględnione będą bodźce do prowadzenia racjonalnej gospodarki finansowej, stymulowania rozwoju gospodarczego, pomnażania źródeł dochodów własnych i wzrostu wysiłku dochodowego lub łączenia się gmin. Informacje na ten temat nie znalazły się w upublicznionym materiale. Nie wspomina się w nim też o dokonywaniu okresowej kontroli efektów wyrównywania nierówności fiskalnych.

Niektóre zmiany odwołują się do dysfunkcji mechanizmu redystrybucji poziomej, które potwierdził Trybunał Konstytucyjny. Chodzi tutaj o ustanowienie udziału w podatku od towarów i usług, który jest dochodem mniej wrażliwym na wahania koniunkturalne niż udziały w podatkach dochodowych. Naprzeciw postulatom Trybunału wychodzą też zmiany polegające na obliczaniu wpłat z uwzględnieniem przeliczeniowej liczby mieszkańców, określeniu górnej granicy wpłaty oraz ustanowieniu reguły, że dochody podatkowe gmin po dokonaniu 
wpłaty nie mogą być niższe od średniego ich poziomu. Zachowaniu płynności finansowej płatników powinno służyć rozwiązanie dopuszczające możliwość obniżenia wpłat o 10\%. Zgodnie z deklaracją Ministerstwa Finansów zaproponowane rozwiązania uwzględniają też to, aby beneficjentami środków wyrównawczych nie były gminy dokonujące wpłat. Szczegółowych informacji na ten temat nie zamieszczono jednak w upublicznionym materiale.

\section{Podsumowanie}

Rozpatrując projekt zmian w mechanizmie wyrównawczym adresowanym do gmin, z perspektywy jego podstawowych komponentów należy stwierdzić, że przedmiotem wyrównania mają być zarówno różnice w zdolności dochodowej, jak i w potrzebach wydatkowych gmin liczonych na mieszkańca przeliczeniowego. Koncepcji tej bliżej jest do modelu jednolitego traktowania gmin, ponieważ uwzględnia się w nim wprawdzie specyfikę niektórych jednostek, ale nie tworzy się dla nich odrębnych formuł wyrównawczych. Jest ona jednak na tyle ogólna, że nie znalazły się w niej zapisy dotyczące skali wyrównania różnic fiskalnych. Lakonicznie potraktowano też opis konstrukcji projektowanego transferu wyrównawczego. W zasadzie wiadomo tylko, że ma to być część subwencji ogólnej oraz że ma być przekazywana gminom najuboższym, a w jej podziale uwzględniana będzie przeliczeniowa liczba mieszkańców. W dalszym ciągu mechanizm wyrównawczy ma mieć charakter mieszany, z dominującą rolą redystrybucji pionowej.

Wstępny projekt zmian w mechanizmie wyrównawczym dla gmin odwołuje się do rekomendacji wypływających z literatury przedmiotu sformułowanych w nurcie teorii federalizmu fiskalnego. Przede wszystkim przewidziano w nim wyrównywanie różnic w potrzebach wydatkowych oraz uwzględnianie specyfiki niektórych gmin (nisko i wysoko zagęszczonych). Oceniany projekt wychodzi także naprzeciw zaleceniom Trybunału Konstytucyjnego odnoszącym się do mechanizmu redystrybucji poziomej i niektórym postulatom zgłaszanym przez innych interesariuszy. 


\section{Literatura}

Ahmad E., Brosio G., Introduction: Fiscal Federalism - a Review of Developments in the Literature and Policy, w: Handbook of Fiscal Federalism, Edward Elgar, Cheltenham, Northampton 2008.

Dafflon B., Fiscal Decentralization, www.ciesin.columbia.edu/decentralization/English/ Issues/Fiscal_d.pdf(23.04.2013).

Gonet W., Partycypacja samorządu terytorialnego w podatkach pośrednich jako źródto dochodów, „Finanse Komunalne” 2012, nr 9.

Grabiński T., Metody taksonometrii, Wydawnictwo Akademii Ekonomicznej w Krakowie, Kraków 1992, s. 34.

Huigsloot P., The equalized allocation of local expenditure needs in the Netherlands: an optimized mixture of objectivity and politics, w: Measuring Local Government Expenditure Needs, The Korea Institute of Public Finance and The Danish Ministry of Social Welfare, Copenhagen 2008.

Izdebski H., Funkcjonowanie instytucji wpłat na subwencję ogólna (,,janosikowe”) $z$ punktu widzenia finansów m.st. Warszawy i województwa mazowieckiego, „Samorząd Terytorialny” 2013, nr 11.

Kańduła S., Metodyka pomiaru potrzeb wydatkowych gmin, „Finanse Komunalne” 2015, w druku.

Kańduła S., Wyrównywanie poziomej nierównowagi finansowej $w$ budżetach gmin w państwach Europy Środkowo-Wschodniej, „Samorząd Terytorialny” 2015, nr 6.

Rekomendacja Komitetu Rady Europy nr 1/2005 z 19.01.2005 r., https://wcd.coe.int/ ViewDoc.jsp? $\mathrm{id}=812131 \&$ Site $=\operatorname{COE}(31.03 .2014)$.

Reschovsky A., Compensating Local Governments for Differences in Expenditure Needs in a Horizontal Fiscal Equalization Program, w: Intergovernmental Fiscal Transfers Principles and Practice, The World Bank, Washington 2007.

Rocznik Statystyczny Rzeczypospolitej Polskiej 2014, GUS, Warszawa 2014.

Shah A., Fiscal need equalization: Is it worth doing? Lessons from international practices, w: Measuring Local Government Expenditure Needs, The Korea Institute of Public Finance and the Danish Ministry of Social Welfare, Copenhagen 2008.

Shah A., Institutional Arrangements for Intergovernmental Fiscal Transfers and a Framework for Evaluation, w: Intergovernmental Fiscal Transfers Principles and Practice, The World Bank, Washington 2007.

Spahn P.B., Equity and Efficiency Aspects of Intragency Transfers in a Multigovernment Framework, w: Intergovernmental Fiscal Transfers Principles and Practice, The World Bank, Washington 2007.

Swianiewicz P., Finanse samorzadowe. Koncepcje, realizacja, polityki lokalne, Wyd. Municipium, Warszawa 2011.

System subwencji i wpłat do budżetu państwa, www.mf.gov.pl (20.06.2015). 
Ustawa z 13.11.2003 r. o dochodach jednostek samorządu terytorialnego, t.j. DzU 2015, poz. 513.

Wyrok Trybunału Konstytucyjnego z 31.01.2013 r., sygn. akt K 14/11 uzupełniony o postanowienie Trybunału Konstytucyjnego z 26.02.2013 r., sygn. akt S 1/13, http:// trybunal.gov.pl/rozprawy/wyroki/ (15.04.2014).

Wyrok Trybunału Konstytucyjnego z 4.03.2014 r., sygn. akt K 13/11, http://trybunal.gov. $\mathrm{pl} /$ rozprawy/wyroki (15.04.2014).

\section{CHANGES IN THE SYSTEM \\ OF LOCAL FISCAL EQUALIZATION MECHANIZM \\ AGAINST THE DEMANDS OF THE FISCAL FEDERALISM THEORY}

\section{Summary}

Article refers to the system of supplementary income for municipalities in Poland, especially to fiscal equalization mechanism. The aim of the article is to present and assess the government's outline of changes in the fiscal equalization mechanism presented in June 2015, against the background of the of fiscal federalism literature. The proposed solutions go primarily to meet the postulate of equalizing the differences in expenditure needs of municipalities. They also take into account the specificity of certain municipalities (population size in small communities, population density). Some of the changes refer not only to the theoretical postulates as to the dysfunction of horizontal redistribution mechanism, which confirmed the Constitutional Court (Tribunal).

Keywords: theory of fiscal federalism, municipal revenues, fiscal equalization 